\title{
Effects of Solid Waste on the Surface Water Quality of Usuma River, Phase IV, Kubwa - Abuja, Nigeria
}

\author{
Ogechukwu Franca Eze ${ }^{1}$, Jibrin Ahmadu ${ }^{1}$, Bessie Hanis ${ }^{2}$ \\ ${ }^{1}$ Department of Pollution Control and Environmental Health, Federal Ministry of Environment, Abuja, Nigeria \\ ${ }^{2}$ National Biotechnology Development Agency, Abuja, Nigeria \\ Email address: \\ francaking.o@gmail.com (O. F. Eze), jigbane2@gmail.com (J. Ahmadu), bessiehanis@gmail.com (B. Hanis) \\ *Corresponding author
}

\section{To cite this article:}

Ogechukwu Franca Eze, Jibrin Ahmadu, Bessie Hanis. Effects of Solid Waste on the Surface Water Quality of Usuma River, Phase IV, Kubwa - Abuja, Nigeria. International Journal of Environmental Protection and Policy. Vol. 7, No. 6, 2019, pp. 150-160. doi: 10.11648/j.ijepp.20190706.13

Received: November 2, 2019; Accepted: December 11, 2019; Published: December 23, 2019

\begin{abstract}
This study has investigated the Effects of Solid Waste on the Surface Water Quality of Usuma River, Phase IV, Kubwa - Abuja. Indiscriminate dump of Municipal Solid Waste generated by households, Phase IV mini market and wastes from parks and hotels around the study area is the major source of pollution of the river. Large tons of wastes dumped at the river bank has often rendered these natural resources unsuitable for both primary and/or secondary usage. Increased agricultural and domestic activities have led to pollution stress on the surface water of this river. This study assessed the impacts of waste disposal on the River Usuma in Phase IV Kubwa, assess the variation in the physio-chemical and biological properties and compare the water quality with WHO standards. Field methods included consultation with Health and Water Quality Expert, collection of water samples at varying distance, laboratory analysis of water samples using standard techniques. The analysis revealed the presence of nitrite $(0.2 \mathrm{mg} / \mathrm{L})$, magnesium $(0.2 \mathrm{mg} / \mathrm{L})$, fluoride $(1.0 \mathrm{mg} / \mathrm{L})$, manganese $(0.2 \mathrm{mg} / \mathrm{L})$ and cadmium $(0.003 \mathrm{mg} / \mathrm{L})$ in higher concentration which is above the WHO benchmark $(7.1 \mathrm{mg} / \mathrm{L}, 0.28 \mathrm{mg} / \mathrm{L}$, $1.04 \mathrm{mg} / \mathrm{L}, 0.61 \mathrm{mg} / \mathrm{L}$ and $0.013 \mathrm{mg} / \mathrm{L}$ ). The presence of these physio-chemical components are indications that the surface water of the study area is likely to be responsible for diseases such as typhoid fever, diarhorea and cholera if it is used for the purpose of drinking. The study also revealed a high Alkalinity with slight changes in turbidity. The contamination varies from one point of the river to another, indicating that the water is unfit for human consumption as a result of the pollution. Accordingly, consultation made with the Health and Water Quality Expert expressed the health implications associated with consumption of water from Usuma River in Phase IV, Kubwa - Abuja. The study has also made recommendations to address the problems revealed such as; improvement of sanitation of the study area, provision of adequate waste management facilities while sensitization of the people is given priority, ensuring clean water in the area and efforts to stop dumping of refuse at the river bank.
\end{abstract}

Keywords: Effects, Solid Waste, Surface Water, Quality, Usuma River and Phase IV, Kubwa

\section{Introduction}

\subsection{Background to the Study}

One of the most critical problems of developing countries is improper management of vast amount of wastes generated by various human activities. Open and indiscriminate dumping of solid wastes in drainage channels and riverbanks is among the problems of improper management of waste in the developing countries of the world [1]. In Nigeria, current urban sanitation infrastructure are inadequate and seem not to be keeping pace with population growth rate. Water bodies, especially freshwater resources, which are the major sources of drinking water, are now major receptacles of treated and untreated or partially treated industrial wastes. These water resources are becoming highly polluted by the activities of the adjoining populations and industrial establishments.

According to United Nations Educational, Scientific and Cultural Organization [2], some 2 million tons of wastes including industrial wastes and chemicals, human wastes and 
agricultural wastes such as fertilizers, pesticides and pesticide residues are dumped into water bodies per day. This has often rendered these natural resources unsuitable for both primary and/or secondary usage [3]. Increased industrial, agricultural and domestic activities have led to pollution stress on surface waters [4]. These wastes alter the physical, chemical and biological nature of the receiving water body. High levels of pollutants in stream water systems cause an increase in biochemical oxygen demand (BOD), chemical oxygen demand (COD), total dissolved solids (TDS), total suspended solids (TSS), toxic metals such as $\mathrm{Cd}, \mathrm{Cr}, \mathrm{Ni}$ and $\mathrm{Pb}$ and faecal coliform hence making such water unsuitable for drinking, irrigation and aquatic life. Water is typically referred to as polluted when it is impaired by anthropogenic contaminants and either does not support a human use, such as drinking water, or undergoes a marked shift in its ability to support its constituent biotic communities, such as fish. As a result of rapid increase in urbanization, industrial and agricultural land use, there is growing appreciation that regionally, nationally, and globally, the management of surface water resources need to be improved and that the amount of waste and pollution generated by human activity reduced. With competing demands on limited water resources, the problem of improper management of both solid and liquid waste should be addressed.

\subsection{Research Questions}

The following research questions were posed in order to facilitate the investigation.

i. i. What is the quality of the surface water of Usuma River in Phase IV, Kubwa?

ii. ii. Is there a variation in the physio-chemical and biological properties of the water with increasing distance in Usuma River in Phase IV, Kubwa?

iii. iii. What is the effect of waste on the surface water quality of Usuma River in Phase IV, Kubwa?

iv. iv. Is the surface water of Usuma River in Phase IV suitable for human consumption?

\subsection{Aim and Objectives}

The aim of this study was to assess the impacts of waste disposal on Usuma River in Phase IV Kubwa. The specific objectives were to:

i. Determine the surface water quality consequent upon solid waste disposal on Usuma River in Phase IV Kubwa;

ii. Determine the variation in the physio-chemical and biological properties of the surface water with increasing distance in the study area;

iii. Assessing the effect of waste on the surface water quality of Usuma River in Phase IV, Kubwa?

iv. Determine the suitability of the surface water of Usuma River for human consumption.

\subsection{Scope of the Study}

This research has spatial, contextual and temporal scope.
In terms of the spatial scope, the study was restricted to Kubwa town only. On the contextual scope, the research was limited to the study of water quality in Phase IV, Usuma River. In terms of temporal scope, water samples were taken in the dry season. The study did not cover other sources of pollution in the study area such as air and noise Pollution.

\section{Conceptual Framework and Literature Review}

\subsection{Concept of Solid Wastes and Water Pollution}

Solid waste is generated from industrial, residential and commercial activities in a given area. In Simple term, Solid wastes are any discarded or abandoned materials that may be solid, liquid, and semi-solid or containerized gaseous material. Waste can be categorized based on its contents, including such materials as plastic, paper, glass, metal, and organic waste. Categorization may also be based on hazard potential, including radioactive, flammable, infectious, toxic, or non-toxic. The menace posed by Municipal solid waste, particularly in the urban areas is one of the gravest environmental challenges facing the world, Nigeria for instance. The problem is exacerbated by urban migration, overpopulation, emergency of urban slums, industrialization, changes in consumption patterns, inadequate planning, lack of resources and facilities to sustainably manage the waste that are being generated. Solid waste management in Nigeria is characterized by inefficient collection methods, insufficient coverage of the collection system and improper disposal. Disposal in most Nigerian cities include, co-disposal of hazardous including hospital wastes with Municipal waste in open, unlined dumpsites, open burning of municipal solid wastes, dumping on water bodies and in other unauthorized place with attendant environmental and health consequences.

Water pollution is a major global problem which requires ongoing evaluation and revision of water resource policy at all levels (international down to individual aquifers and wells). It has been suggested that water pollution is the leading worldwide cause of deaths and diseases and that it accounts for the deaths of more than 14,000 people daily. Water pollution almost, always means that some damage has been done to an ocean, river, lake, or other water source. "The introduction by man, directly or indirectly, of substances or energy into the marine environment (including estuaries) resulting in such deleterious effects as harm to living resources, hazards to human health, hindrance to marine activities, including fishing, impairment of quality for use of sea water and reduction of amenities." - [5].

Thus, water pollution is all about quantities: how much of a polluting substance is released and how big a volume of water it is released into. Virtually any human activity can have an effect on the quality of our water environment. When farmers fertilize the fields, the chemicals they use are gradually washed by rain into the groundwater or surface waters nearby. Sometimes the causes of water pollution are quite surprising. Chemicals released by smokestacks 
(chimneys) can enter the atmosphere and then fall back to earth as rain, entering seas, rivers, and lakes and causing water pollution. There are also two different ways in which pollution can occur; if pollution comes from a single location, such as a discharge pipe attached to a factory, it is known as point-source pollution. But when the water polluted is not from one single source but from many different scattered sources, it is called nonpoint-source pollution.

The awareness on water pollution due to waste disposal is high among the communities that live within the catchment as their educational level is good. However, discharge of gray water as well as black water by people who live close to the canal is evident. Though their awareness on water pollution and possible consequences is high, they still continue to practise these activities due to lack of options for proper disposal of solid and liquid wastes.

\subsection{Literature Review}

During the last decade of the $20^{\text {th }}$ century, environmental issues received an unprecedented attention at the international level. It is an indisputable fact that waste is the most visible and serious environmental problem facing Nigeria's urban and semi-urban centres [6-9]. Urbanization is believed to be an important cause of destruction and degradation of natural water resources. With rural-urban migration, it has been estimated that by the year 2025, approximately fifty percent of the population will live in growing cities of less developed countries. A feature of the urban scene in Nigeria in recent years is the gradual takeover of virtually every available open space by refuses. The refuse dumps apart from physically obstructing legitimate human activities, have become fertile grounds for breeding flies, mosquitoes, rodents, among other, pests that have constituted the dumps into grave health hazards.

The management of waste is an activity carried out by any community or society as a means by which waste i.e. all those materials and substances which are valueless and have been rejected and are of potential harm or outright hazard to life and the environment are removed from the sphere of human living [10-12]. It involves the coordination of certain processes and schemes, which facilitate the efficient disposal of these wastes, and is therefore run as a system by a designated authority such as the regional government, which is sometime assisted by private sector participation $[10,13$, 14] opined that the provision of functional waste collection mechanism, the trapping, containment and treatment of dangerous wastes before they reach and pollute the environment constitute an important component of waste management. According to [15], the fundamental approach to waste in its management comprises; the collection and packaging of the waste; the manipulation of the waste and final disposal.

\subsubsection{Effects of Poor Water Quality on Water Quantity}

Assert that water quality degradation is a principal cause of water scarcity and could reduce the amount of freshwater available for domestic, agricultural and industrial use [16]. The quantity of available freshwater is thus linked to quality which may limit its use [17]. Human activities such as the indiscriminate dumping of refuse and channelling of untreated domestic and industrial effluents into rivers reduce water quality and also reduce the uses to which water can be put. Poor water quality has an impact on the quantity of potable water in a number of ways. Generally, treatment processes for polluted water remove pollutants through creation of a waste sludge. The poorer the water quality of the source water, the greater the level of treatment that will be required to bring it to a useable standard, and the less clean the water that will result from treatment. Also, more polluted water requires a significant amount of energy to treat.

\subsubsection{Physical Characteristics of Wastewater}

The most important physical characteristics of wastewater are its temperature and its solids concentration [18]. The temperature influences chemical reactions and biological activities whiles solids, affect the operation and sizing of treatment units [19]. The Solids consist of matter suspended or dissolved in water and wastewater [18]. Dissolved solids refer to the portion of solids that passes through a filter of 2.0 $\mu \mathrm{m}$ (or smaller) nominal pore size under specified conditions while the portion retained on the filter is the suspended solids. Other important physical characteristics include particle size distribution, colour, transmittance, conductivity, density, specific gravity, specific weight and odour [20].

In terms of colour, fresh wastewater is usually a light brownish-gray colour [21]. Odours in wastewater are generally as a result of gases produced by the decomposition of organic matter or by other substances added to the wastewater [21]. Fresh domestic wastewater has a musty odour and changes to a rotten egg odour in septic wastewater due to the production of hydrogen sulphide. Electrical conductivity (EC) is a measure of the capacity of an aqueous solution to conduct an electric current due to the presence of ions. Electrical conductivity (EC) increases with increasing concentration of ions and temperature of solution. [22] established that, EC increases by approximately 2 percent per ${ }^{\circ} \mathrm{C}$ increase in temperature.

\subsubsection{Chemical Characteristics of Wastewater}

The chemical constituents of wastewater are typically classified as inorganic and organic [20]. Inorganic chemical parameters according to [19], include salinity, hardness, $\mathrm{pH}$, alkalinity, iron, manganese, chlorides, sulphates, sulphides, heavy metals (Mercury, lead, chromium, Copper, and Zinc), nitrogen (organic, ammonia, nitrite, and nitrate) phosphorus and gases. The $\mathrm{pH}$ of wastewater indicates the activity of hydrogen ions and describes its acidity or basicity. Wastewater becomes extremely difficult to treat by biological means if it has excessive concentration of hydrogen ion (low $\mathrm{pH}$ ) [20]. According to [23], $\mathrm{pH}$ is very important in an aquatic environment to many metabolic reactions in microbial cells, which includes energy generation and ion transport. 
Phosphorus in domestic wastewater normally originates from phosphate compounds in detergents [18] and usually exists in the form of orthophosphate, polyphosphate and organic phosphate [20]. The orthophosphates are available for biological metabolism without further breakdown while the polyphosphates undergo hydrolysis and revert to the orthophosphate forms in aqueous solution. Nitrogen compounds in wastewater originate principally from plant and animal origin, sodium nitrate and atmospheric nitrogen. It exists in wastewater usually in the form of ammonia $\left(\mathrm{NH}_{3}\right)$, ammonium $\left(\mathrm{NH}_{4}^{+}\right)$, nitrogen gas $\left(\mathrm{N}_{2}\right)$, nitrite ion $\left(\mathrm{NO}_{2}^{-}\right)$and nitrate ion $\left(\mathrm{NO}_{3}^{-}\right)$[15]. Chemical parameters associated with the organic content of wastewater include the Biochemical Oxygen Demand (BOD), Chemical Oxygen Demand (COD), Total Organic Carbon (TOC), and Total Oxygen Demand (TOD). Both BOD and COD are often used as a measurement of pollutants in wastewater and natural waters. Primarily, BOD as explained by Reynolds et al. 2002, is the level of organic content in wastewater measured by the demand for oxygen that can be consumed by living organisms in the wastewater. Wastewater with high BOD content is characterized by low oxygen content and high biological activity.

Chemical Oxygen Demand, according to [21] measures the amount of oxidizable matter present in wastewater. It increases significantly with the presence of industrial wastes. Because nearly all organic compounds are oxidized in the COD test, while only some are decomposed during the BOD test, COD results are always higher than BOD results [24]. However, COD does not differentiate between biologically degradable and non-degradable organic matter. According to [25], biological degradation consumes the oxygen present in surface water and results in anaerobic conditions, odour formation, fish kills and ecological imbalance. The sources of BOD according to [21] include leaves and wood debris; dead plants and animals; animal manure; effluents from pulp and papermills, wastewater treatment plants, feedlots, and foodprocessing plants; failing septic systems; and urban stormwater runoff.

The study of [19] reported that, heavy metals are usually added to wastewater from commercial and industrial activities and may have to be removed if the wastewater is to be reused. Many of these metals such as Cadmium (Cd), Chromium $(\mathrm{Cr})$, Copper $(\mathrm{Cu})$, Iron $(\mathrm{Fe})$, Lead $(\mathrm{Pb})$, Manganese $(\mathrm{Mn})$, Mercury $(\mathrm{Hg}), \operatorname{Nickel}(\mathrm{Ni})$ and Zinc $(\mathrm{Zn})$ in trace quantities, promote the growth of biological life in most waters. However, in excessive quantities they become toxic and interfere with many beneficial uses of the water.

\subsubsection{Biological Characteristics of Wastewater}

The major groups of microorganisms present in wastewater are bacteria, fungi, protozoa, microscopic plants and animals, viruses and helminths [18]. Most microorganisms (bacteria, protozoa) are responsible and also beneficial for biological treatment processes of wastewater [19]; [18]. However, [23] reported that, depending on the dose and susceptibility of the host, some of these organisms found in wastewater can cause diseases of the gastrointestinal tract such as typhoid and paratyphoid fever, dysentery, diarrhoea and cholera.

The study of [26] reported that faecal coliforms are the most commonly used indicator bacteria for faecal contamination, since their excreted load is similar or larger than that of pathogenic organisms, and their survival time in the environment is longer.

\subsubsection{Surface Water Quality Monitoring}

Water quality monitoring, as defined by UNESCO/WHO/UNEP 2006 refers to the actual collection of information at specific locations and at regular intervals in order to provide data, which may be used to define current conditions, establish trends, etc. According to [25] and [27], water quality monitoring is an essential tool for environmental agencies to determine the quality of water bodies and make management decisions for improving or protecting the intended uses. It is therefore necessary that consistent information on water quality is collected, analysed and evaluated in a timely and efficient manner [25]

To achieve this, authors of various guidelines for surface water monitoring [28, 30] assert that appropriate documentation of data and the use of clean sampling equipment are imperative. [29] also recommends that, the hydrology and morphometric (eg measurements of volume, depth, etc.) of a stream or impoundment are also important factors to be determined prior to sampling. This will aid in determining the presence of phases or layers in Streams or impoundments, flow patterns in streams, and appropriate sample locations and depths.

The water samples can be in the form of grab or composite samples depending on the field conditions and study data needs $[28,30]$. A surface grab sample may be necessitated based on the following conditions; stream velocity is such that penetration to depth is not easily obtained, surface sheen/film is identified, low water exists, or a sample from the upper surface of the water body is required [30]. But when the sample will be used to describe general water quality bracketing a period of time, a composite sample can be collected using an automated composite sampler.

\section{Research Methodology}

This section has examined the methods used in the collection and analyses of water sample that was required to address the aim and objectives of the study.

\subsection{Reconnaissance Survey}

In carrying out this study, a reconnaissance survey of the study area was carried out to select the appropriate collection points for water sample within the stream.

\subsection{Materials Used for Water Sample Collection}

The basic materials and equipment that were used in carrying out this study are presented thus: 
i. One litre of plastic container for each sample

ii. Masking tape

iii. Marker

iv. Writing pad

v. Cooler/Cool box

vi. Ranging Poles

vii. Measuring Tape

\subsection{Sampling Procedure}

Three sampling points were identified in the study area; an upstream point, that is, 200metres away before the waste dump, contact point where the waste is dumped and another 200 meters away from the contact point, that is the downstream.

The surface water sample was collected in October, 2017 and the sampling container rinsed with nitric acid. This was to avoid the contamination of the container. After collection, nitric acid $(0.2 \%)$ was added as a preservative. The samples marked and labelled after the source of water, sampling location and date of water sample collection. The collected sample was preserved in plastic coolers containing ice-block and transported to the laboratory for analysis. $\mathrm{pH}$ of the water samples was determined in-situ during samples collections.

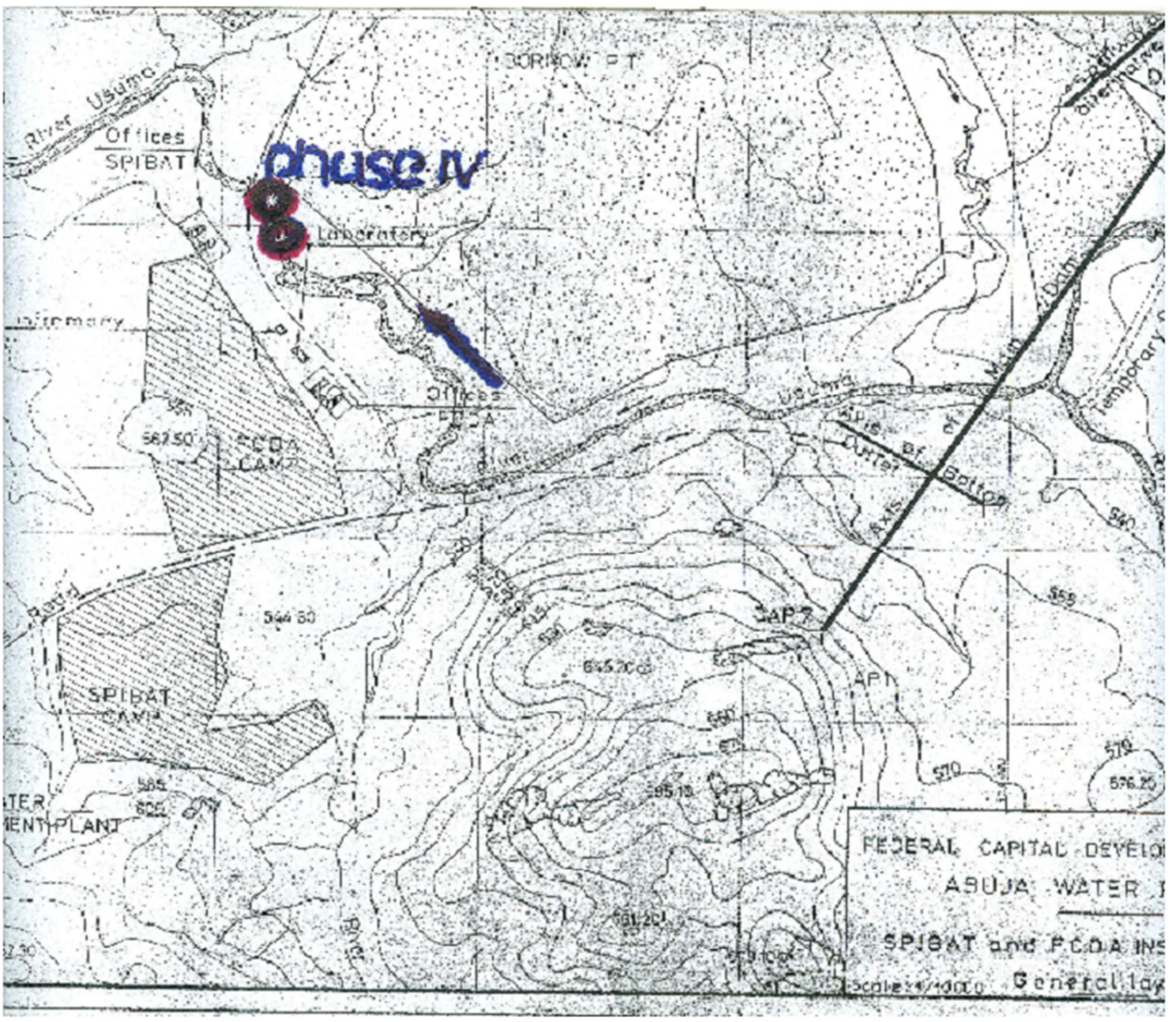

Figure 1. The Phase IV Usuma River Indicating the Sample Points.

\subsection{Water Sample Analyses}

Apart from the $\mathrm{pH}$ measurement that was done in-situ, all other analysis were done using Analyst100 (Perkin-Elmer) Spectrophotometer located at the Analytical Laboratory accredited by the Federal Ministry of Environment in Abuja. For instance, the $\mathrm{pH}$ measurement was carried out at $25.8^{\circ} \mathrm{C}$ using an E603 Metrohm pH-meter equipped with a glass electrode. The $\mathrm{pH}$-meter was calibrated against Crison buffer standard solutions. Heavy metal analyses was carried out using atomic absorption spectroscopy (AAS) with electrothermic atomization in graphite furnace for the determination of the total content of $\mathrm{Al}, \mathrm{Cr}, \mathrm{Mn}, \mathrm{Fe}, \mathrm{Co}, \mathrm{Ni}, \mathrm{Cu}, \mathrm{Zn}, \mathrm{As}, \mathrm{Cd}$ and $\mathrm{Pb}$. The instrument used was Analyst100 (Perkin-Elmer) spectrophotometer located at the Analytical Laboratory. The machine was equipped with an HGA-800 furnace and an AS72 Autosampler.

The microbiological test was also carried out by 
disinfecting thoroughly the cap of the bottles and aseptically introducing a sterile pipette which was used to suck out the required volume. $12.5 \mathrm{ml}$ of each sample was aseptically added to $112.5 \mathrm{ml}$ of sterile diluents contained in a $125 \mathrm{ml}$ conical flask. Then shaken vigorously with downward and upward motion. The data obtained for this study were compared with the WHO standards to determine if there is significant variation in surface water quality of Usuma River in phase IV for human consumption.

\subsection{Consultation with Health and Water Quality Expert}

The Health and Water Quality Expert was consulted in order to determine the health implication of consuming polluted water.

\section{Results and Discussion}

This Chapter presents the results of field survey, laboratory analysis of water samples collected as well as the presumed implication on human health.

\subsection{Surface Water Quality of the Usuma River in Phase IV}

The objective one of this study is to determine the surface water quality consequent upon solid waste disposal on the Usuma River in Phase IV, Kubwa.

Table 1. Analysed Results of the five (5) samples obtained from Point 1.

\begin{tabular}{|c|c|c|c|c|c|c|c|}
\hline $\mathbf{S} / \mathbf{N}$ & Parameters & WHO Max. Limit & Sample 1 & Sample 2 & Sample 3 & Sample 4 & Sample 5 \\
\hline \multirow{2}{*}{1} & \multirow{2}{*}{ Packaging } & & Food Grade & Food Grade & Food Grade & Food Grade & Food Grade \\
\hline & & & Wrapper & Wrapper & Wrapper & Wrapper & Wrapper \\
\hline 2 & Color (TCU) & 15 & $5 \mathrm{TCU}$ & 5 & 6 & 7 & 7 \\
\hline 4 & Temperature & Ambient & Ambient & Ambient & Ambient & Ambient & Ambient \\
\hline 5 & Turbidity (NTU) & 5.00 & 1.00 & 1.00 & 1.03 & 1.04 & 1.05 \\
\hline 7 & Fluoride (mg/L) & 1.00 & 0.32 & 0.22 & 0.21 & 0.20 & 0.26 \\
\hline 8 & Copper (mg/L) & 1.00 & 0.14 & 0.12 & 0.10 & 0.11 & 0.14 \\
\hline 9 & Iron $(\mathrm{mg} / \mathrm{L})$ & 0.30 & 0.07 & 0.07 & 0.06 & 0.05 & 0.05 \\
\hline 10 & Nitrate $(\mathrm{mg} / \mathrm{L})$ & 50.0 & 32.02 & 33.1 & 32.0 & 32.03 & 32.21 \\
\hline 11 & Nitrite (mg/L) & 0.20 & 7.00 & 7.00 & 7.02 & 7.03 & 7.10 \\
\hline 12 & Manganese (mg/L) & 0.20 & 0.16 & 0.12 & 0.30 & 0.30 & 0.32 \\
\hline 13 & Magnesium (mg/L) & 0.20 & 0.27 & 0.18 & 0.22 & 0.18 & 0.16 \\
\hline 14 & Zinc $(\mathrm{mg} / \mathrm{L})$ & 3.00 & 1.05 & 1.20 & 1.21 & 1.21 & 1.21 \\
\hline 16 & $\mathrm{pH}$ & $6.5-8.5$ & 7.84 & 7.84 & 7.58 & 7.50 & 7.40 \\
\hline 17 & Hardness (mg/L) & 150.0 & 120.0 & 110.0 & 95.0 & 95.0 & 95.0 \\
\hline 18 & Total Alkalinity (mg/L) & 50.0 & 50.0 & 50.0 & 49.0 & 49.0 & 49.04 \\
\hline 19 & Hydrogen Sulphide (mg/L) & 0.05 & 0.03 & 0.03 & 0.03 & 0.03 & 0.028 \\
\hline 20 & Sulphate (mg/L) & 100.0 & 0.00 & 0.00 & 0.00 & 0.05 & 0.05 \\
\hline 21 & Conductivity (us/Cm) & 1000 & 172.0 & 135.0 & 135.0 & 13500 & 133.0 \\
\hline 22 & Lead (mg/L) & 0.01 & 0.008 & 0.008 & 0.008 & 0.008 & 0.005 \\
\hline 23 & Cyanide (mg/L) & 0.01 & 0.001 & 0.001 & 0.001 & 0.001 & 0.001 \\
\hline 24 & Cadmium (mg/L) & 0.00 & 0.003 & 0.003 & 0.003 & 0.003 & 0.003 \\
\hline 25 & Arsenic (mg/L) & 0.01 & 0.004 & 0.004 & 0.004 & 0.003 & 0.003 \\
\hline 26 & Barium (mg/L) & 0.70 & 0.006 & 0.006 & 0.003 & 0.003 & 0.003 \\
\hline 27 & Mercury (mg/L) & 0.01 & 0.002 & 0.002 & 0.002 & 0.002 & 0.002 \\
\hline 28 & Free Residual Chloride (mg/L) & $0.2-0.25$ & 0.03 & 0.03 & 0.03 & 0.03 & 0.03 \\
\hline 29 & Polyaromatic Hydrocarbon (mg/L) & 0.007 & 0.001 & 0.001 & 0.001 & 0.001 & 0.001 \\
\hline 30 & Total Organic Carbon (mg/L) & 5.00 & 1.05 & 1.65 & 1.65 & 1.67 & 1.67 \\
\hline 33 & 2, 4, 6-Trichlorophen-ol (mg/L) & 0.02 & 0.002 & 0.001 & 0.001 & 0.001 & 0.001 \\
\hline \multicolumn{8}{|c|}{ MICRO-BIOLOGY } \\
\hline 34 & Clostridium per Fringe & Nill & Nill & Nill & Nill & Nill & Nill \\
\hline 35 & Chromo Bacterium violaceum & Nill & Nill & Nill & Nill & Nill & Nill \\
\hline 36 & E. Coli & Nill & Nill & Nill & Nill & Nill & Nill \\
\hline 37 & Faecal Streptococci & Nill & Nill & Nill & Nill & Nill & Nill \\
\hline 38 & Total Coliform Count & $10 \mathrm{cfu} / \mathrm{Ml}$ & 3 & $10 \mathrm{cfu} / \mathrm{Ml}$ & 2 & & \\
\hline 39 & S. Aureus & Nill & Nill & Nill & Nill & Nill & Nill \\
\hline 40 & Yeast/Mould & Nill & Nill & Nill & Nill & Nill & Nill \\
\hline
\end{tabular}

Source: Laboratory Analysis of Sample 2017 
Table 2. Analysed Results of the five (5) samples obtained from Point 2.

\begin{tabular}{|c|c|c|c|c|c|c|c|}
\hline $\mathbf{S} / \mathbf{N}$ & Parameters & $\begin{array}{l}\text { WHO Req. } \\
\text { Max. Limit }\end{array}$ & Sample 1 & Sample 2 & Sample 3 & Sample 4 & Sample 5 \\
\hline \multirow{2}{*}{1} & \multirow{2}{*}{ Packaging } & & Food Grade & Food Grade & Food Grade & Food Grade & Food Grade \\
\hline & & & Wrapper & Wrapper & Wrapper & Wrapper & Wrapper \\
\hline 2 & Color (TCU) & $15 \mathrm{TCU}$ & 9TCU & 9TCU & 9TCU & & \\
\hline 3 & Taste/Odor & Unobjectionable & Unobjecti-onable & Unobjecti-onable & Unobjecti-onable & Unobjecti-onable & Unobjecti-onable \\
\hline 4 & Temperature & Ambient & Ambient & Ambient & Ambient & Ambient & Ambient \\
\hline 5 & Turbidity (NTU) & 5.0 & 3.0 & 3.0 & 3.03 & 3.02 & 3.03 \\
\hline 7 & Fluoride (mg/L) & 1.00 & 1.02 & 1.02 & 1.04 & 1.04 & 1.03 \\
\hline 8 & Copper $(\mathrm{mg} / \mathrm{L})$ & 1.00 & 0.12 & 0.12 & 0.12 & 0.12 & 0.11 \\
\hline 9 & $\operatorname{Iron}(\mathrm{mg} / \mathrm{L})$ & 0.30 & 0.02 & 0.02 & 0.02 & 0.02 & 0.02 \\
\hline 10 & Nitrate $(\mathrm{mg} / \mathrm{L})$ & 50.0 & 13.10 & 13.11 & 13.12 & 13.13 & 13.11 \\
\hline 11 & Nitrite (mg/L) & 0.20 & 0.00 & 0.00 & 0.00 & 0.00 & 0.00 \\
\hline 12 & Manganese (mg/L) & 0.20 & 0.16 & 0.16 & 0.16 & 0.15 & 0.15 \\
\hline 13 & Magnesium (mg/L) & 0.20 & 0.18 & 0.18 & 0.18 & 0.17 & 0.17 \\
\hline 16 & $\mathrm{pH}$ & $6.5-8.5$ & 7.80 & 7.80 & 7.81 & 7.81 & 7.81 \\
\hline 17 & Hardness (mg/L) & 150.0 & 41.0 & 41.0 & 40.0 & 40.0 & 40.0 \\
\hline 18 & Total Alkalinity (mg/L) & 50.0 & 58.0 & 58.0 & 57.0 & 57.0 & 55.0 \\
\hline 19 & Hydrogen Sulphide (mg/L) & 0.05 & 0.01 & 0.01 & 0.01 & 0.01 & 0.01 \\
\hline 20 & Sulphate (mg/L) & 100.0 & 0.00 & 0.00 & 0.00 & 0.00 & 0.00 \\
\hline 21 & Conductivity (us/Cm) & 1000 & 71.0 & 71.0 & 78.0 & 72.00 & 72.00 \\
\hline 22 & Lead (mg/L) & 0.01 & 0.002 & 0.002 & 0.001 & 0.002 & 0.002 \\
\hline 23 & Cyanide (mg/L) & 0.01 & 0.001 & 0.001 & 0.001 & 0.001 & 0.001 \\
\hline 24 & Cadmium $(\mathrm{mg} / \mathrm{L})$ & 0.003 & 0.001 & 0.001 & 0.001 & 0.001 & 0.001 \\
\hline 25 & Arsenic (mg/L) & 0.01 & 0.004 & 0.003 & 0.004 & 0.004 & 0.003 \\
\hline 26 & Barium (mg/L) & 0.70 & 0.006 & 0.006 & 0.005 & 0.005 & 0.005 \\
\hline 27 & Mercury (mg/L) & 0.01 & 0.002 & 0.001 & 0.002 & 0.002 & 0.002 \\
\hline 28 & Free Residual Chloride (mg/L) & $0.2-0.25$ & 0.06 & 0.06 & 0.06 & 0.005 & 0.006 \\
\hline 29 & Polyaromatic Hydrocarbon (mg/L) & 0.007 & 0.005 & 0.005 & 0.005 & 0.005 & 0.005 \\
\hline 30 & Total Organic Carbon (mg/L) & 5.00 & 0.65 & 0.68 & 0.68 & 0.70 & 0.71 \\
\hline 33 & 2, 4, 6 Trichlorophen-ol (mg/L) & 0.02 & 0.001 & 0.001 & 0.001 & 0.001 & 0.001 \\
\hline $\mathrm{MIC}$ & -BIOLOGY & & & & & & \\
\hline 34 & Clostridium per Fringe & Nill & Nill & Nill & Nill & Nill & Nill \\
\hline 35 & Chromo Bacterium violaceum & Nill & Nill & Nill & Nill & Nill & Nill \\
\hline 36 & E. Coli & Nill & Nill & Nill & Nill & & Nill \\
\hline 37 & Faecal Streptococci & Nill & Nill & Nill & Nill & Nill & Nill \\
\hline 38 & Total Coliform Count & $10 \mathrm{cfu} / \mathrm{Ml}$ & 3 & $10 \mathrm{cfu} / \mathrm{Ml}$ & 2 & & \\
\hline 39 & S. Aureus & Nill & Nill & Nill & Nill & Nill & Nill \\
\hline 40 & Yeast/Mould & Nill & Nill & Nill & Nill & Nill & Nill \\
\hline
\end{tabular}

Source: Laboratory Analysis of Sample 2017

Table 3. Analysed Results of the five (5) samples obtained from Point 3.

\begin{tabular}{|c|c|c|c|c|c|c|c|}
\hline $\mathbf{S} / \mathbf{N}$ & Parameters & WHO Max. Limit & Sample 1 & Sample 2 & Sample 3 & Sample 4 & Sample 5 \\
\hline \multirow{2}{*}{1} & \multirow{2}{*}{ Packaging } & & Food Grade & Food Grade & Food Grade & Food Grade & Food Grade \\
\hline & & & Wrapper & Wrapper & Wrapper & Wrapper & Wrapper \\
\hline 2 & Color (TCU) & $15 \mathrm{TCU}$ & 9TCU & 9TCU & 9TCU & & \\
\hline 3 & Taste/Odor & Unobjectionable & $\begin{array}{l}\text { Unobjecti- } \\
\text { onable }\end{array}$ & $\begin{array}{l}\text { Unobjecti- } \\
\text { onable }\end{array}$ & $\begin{array}{l}\text { Unobjecti- } \\
\text { onable }\end{array}$ & $\begin{array}{l}\text { Unobjecti- } \\
\text { onable }\end{array}$ & $\begin{array}{l}\text { Unobjecti- } \\
\text { onable }\end{array}$ \\
\hline 4 & Temperature & Ambient & Ambient & Ambient & Ambient & Ambient & Ambient \\
\hline 5 & Turbidity (NTU) & 5.0 & 6.0 & 6.2 & 6.0 & 6.0 & 6.0 \\
\hline 7 & Fluoride (mg/L) & 1.00 & 0.86 & 0.84 & 0.85 & 0.85 & 0.86 \\
\hline 8 & Copper (mg/L) & 1.00 & 0.90 & 0.92 & 0.91 & 0.90 & 0.90 \\
\hline 9 & Iron $(\mathrm{mg} / \mathrm{L})$ & 0.30 & 0.12 & 0.12 & 0.12 & 0.12 & 0.12 \\
\hline 10 & Nitrate $(\mathrm{mg} / \mathrm{L})$ & 50.0 & 0.00 & 0.00 & 0.00 & 0.00 & 0.00 \\
\hline 11 & Nitrite (mg/L) & 0.20 & 0.00 & 0.00 & 0.00 & 0.00 & 0.00 \\
\hline 12 & Manganese (mg/L) & 0.20 & 0.60 & 0.60 & 0.61 & 0.61 & 0.60 \\
\hline 13 & Magnesium (mg/L) & 0.20 & 0.12 & 0.12 & 0.12 & 0.11 & 0.11 \\
\hline 14 & Zinc $(\mathrm{mg} / \mathrm{L})$ & 3.00 & 1.14 & 1.14 & 1.14 & 1.14 & 1.14 \\
\hline
\end{tabular}




\begin{tabular}{|c|c|c|c|c|c|c|c|}
\hline $\mathbf{S} / \mathbf{N}$ & Parameters & WHO Max. Limit & Sample 1 & Sample 2 & Sample 3 & Sample 4 & Sample 5 \\
\hline 16 & $\mathrm{pH}$ & $6.5-8.5$ & 7.61 & 7.64 & 7.65 & 7.63 & 7.65 \\
\hline 17 & Hardness (mg/L) & 150.0 & 51.0 & 55.0 & 51 & 50 & 50 \\
\hline 18 & Total Alkalinity (mg/L) & 50.0 & 57.0 & 58.0 & 58.5 & 57 & 57 \\
\hline 19 & Hydrogen Sulphide (mg/L) & 0.05 & 0.01 & 0.01 & 0.01 & 0.01 & 0.01 \\
\hline 20 & Sulphate (mg/L) & 100 & 0.00 & 0.00 & 0.00 & 0.00 & 0.00 \\
\hline 21 & Conductivity (us/Cm) & 1000 & 103.0 & 91.0 & 98 & 100 & 100 \\
\hline 22 & Lead $(\mathrm{mg} / \mathrm{L})$ & 0.01 & 0.006 & 0.006 & 0.006 & 0.006 & 0.006 \\
\hline 24 & Cadmium (mg/L) & 0.003 & 0.012 & 0.013 & 0.012 & 0.012 & 0.012 \\
\hline 25 & Arsenic (mg/L) & 0.01 & 0.006 & 0.006 & 0.006 & 0.006 & 0.006 \\
\hline 26 & Barium (mg/L) & 0.70 & 0.003 & 0.003 & 0.003 & 0.003 & 0.003 \\
\hline 27 & Mercury (mg/L) & 0.01 & 0.002 & 0.003 & 0.003 & 0.002 & 0.002 \\
\hline 28 & $\begin{array}{l}\text { Free Residual } \\
\text { Chloride }(\mathrm{mg} / \mathrm{L})\end{array}$ & $0.2-0.25$ & 0.00 & 0.00 & 0.00 & 0.00 & 0.00 \\
\hline 29 & Polyaromatic Hydrocarbon(mg/L) & 0.007 & 0.005 & 0.005 & 0.005 & 0.005 & 0.005 \\
\hline 32 & Phenol (mg/L) & 0.001 & 0.001 & 0.001 & 0.001 & 0.001 & 0.001 \\
\hline 33 & 2, 4, 6- Trichlorophen-ol (mg/L) & 0.02 & 0.001 & 0.001 & 0.001 & 0.001 & 0.001 \\
\hline \multicolumn{8}{|c|}{ MICRO-BIOLOGY } \\
\hline 34 & Clostridium per Fringe & Nill & Nill & Nill & Nill & Nill & Nill \\
\hline 35 & Chromo Bacterium violaceum & Nill & Nill & Nill & Nill & Nill & Nill \\
\hline 36 & E. Coli & Nill & Nill & Nill & Nill & Nill & Nill \\
\hline 37 & Faecal Streptococci & Nill & Nill & Nill & Nill & Nill & Nill \\
\hline 38 & Total Coliform Count & $10 \mathrm{cfu} / \mathrm{Ml}$ & 3 & $10 \mathrm{cfu} / \mathrm{Ml}$ & 2 & 2 & 2 \\
\hline 39 & S. Aureus & Nill & Nill & Nill & Nill & Nill & Nill \\
\hline 40 & Yeast/Mould & Nill & Nill & Nill & Nill & Nill & Nill \\
\hline
\end{tabular}

Source: Laboratory Analysis of Sample 2017

\subsection{Variation in the Physio-Chemical and Biological Properties of the Surface Water with Increasing Distance in the Study Area}

(1) The result of the analysis revealed that most of the parameters are within the required WHO threshold with increasing distance of 200 meters in the random collection of five samples in point 1 except for Nitrite and Magnesium while the WHO required bench mark for Nitrite $(0.2 \mathrm{mg} / \mathrm{l})$ and Magnesium $(0.20 \mathrm{mg} / \mathrm{l})$. This means that there is variation in Nitrite and magnesium in the Five (5) samples analysed with increased distance in point 1 .

(2) The result of the analysis revealed that most of the parameters are within the required WHO threshold with increasing distance of 200 meters in the random collection of five samples in point 2 except for Fluoride $(1.02 \mathrm{mg} / 1$, and $1.04 \mathrm{mg} / \mathrm{l}$ ) which is above the WHO required bench mark for Fluoride of $1.0 \mathrm{mg} / 1$ This means that there is variation in the physio-chemical properties of fluoride in the Five (5) samples analysed with increased distance in point 2. This also means that the surface water of the study area has high concentration of Fluoride with an increased distance 200meters from point of waste dump.

(3) The result of the analysis revealed that most of the parameters are within the required WHO threshold with increasing distance of 200 meters in the random collection of five samples in point 3 except for Manganese $(0.60 \mathrm{mg} / \mathrm{l})$ and Cadmium $(0.012 \mathrm{mg} / \mathrm{L})$ which is above the WHO required bench mark for Manganese and Cadmium of $0.2 \mathrm{mg} / \mathrm{L}$ and $0.003 \mathrm{mg} / \mathrm{L}$. This means that there is variation in the physiochemical properties of Manganese in the Five (5) samples analysed with increased distance in point 3 . This also means that the surface water of the study area has high concentration of Manganese with an increased distance 200 meters from point of waste dump.

\subsection{The Effect of Waste on the Surface Water Quality of Usuma River in Phase IV, Kubwa at the three (3) Various Points}

The analysis shows that Color (15TCU), Taste/Odor (Unobjectionable), Temperature (Ambient), Turbidity (5.0NTU), Chloride (100mg/L), Fluoride (1.02mg/L), Copper $(1.0 \mathrm{mg} / \mathrm{L})$, Iron $(0.3 \mathrm{mg} / \mathrm{L})$, Nitrate $(50 \mathrm{mg} / \mathrm{L})$, Magnesium $(0.2 \mathrm{mg} / \mathrm{L})$, Zinc $(3.0 \mathrm{mg} / \mathrm{L})$, TDS $(500 \mathrm{mg} / \mathrm{L}), \mathrm{pH}(6.5-8.5)$, Hardness (150mg/L), Total Alkalinity $(50 \mathrm{mg} / \mathrm{L}), \mathrm{H}_{2} \mathrm{~S}$ $(0.05 \mathrm{mg} / \mathrm{L})$, Sulphate $(100 \mathrm{mg} / \mathrm{L})$, Conductivity $(1000 \mathrm{us} / \mathrm{cm})$, Lead $\quad(0.01 \mathrm{mg} / \mathrm{L}), \quad$ Cyanide $\quad(0.01 \mathrm{mg} / \mathrm{L}), \quad$ Cadmium $(0.003 \mathrm{mg} / \mathrm{L})$ Arsenic $(0.01 \mathrm{mg} / \mathrm{L}), \quad$ Barium $(0.7 \mathrm{mg} / \mathrm{L})$, Mercury $(0.01 \mathrm{mg} / \mathrm{L})$, Free Residual Chloride $(0.2-0.25 \mathrm{mg} / \mathrm{L})$, Poly Aromatic HC $(0.007 \mathrm{mg} / \mathrm{L})$, Total Organic Carbon $(5.0 \mathrm{mg} / \mathrm{L})$, Mineral oil $(0.003 \mathrm{mg} / \mathrm{L})$, Phenol $(0.001 \mathrm{mg} / \mathrm{L}), 2$, 4, 6-TrichloroPhenol $(0.02 \mathrm{mg} / \mathrm{L})$, are within the required WHO standard recommended for domestic use while Nitrite $(7.0 \mathrm{mg} / \mathrm{L})$ and Magnesium $(0.6 \mathrm{mg} / \mathrm{L})$ are above the WHO standard of Nitrite $(0.2 \mathrm{mg} / \mathrm{L})$ and Manganese $(0.2 \mathrm{mg} / \mathrm{L})$.

The analysis shows that Color (15TCU), Taste/Odor (Unobjectionable), Temperature (Ambient), Turbidity (5.0NTU), Chloride (100mg/L), Fluoride (1.02mg/L), Copper $(1.0 \mathrm{mg} / \mathrm{L})$, Iron $(0.3 \mathrm{mg} / \mathrm{L})$, Nitrate $(50 \mathrm{mg} / \mathrm{L})$, Nitrite $(0.2 \mathrm{mg} / \mathrm{L})$, Manganese $(0.2 \mathrm{mg} / \mathrm{L})$, Magnesium $(0.2 \mathrm{mg} / \mathrm{L})$, Zinc $(3.0 \mathrm{mg} / \mathrm{L})$, TDS $(500 \mathrm{mg} / \mathrm{L})$, pH $(6.5-8.5)$, Hardness (150mg/L), Total Alkalinity (50mg/L), $\mathrm{H}_{2} \mathrm{~S} \quad(0.05 \mathrm{mg} / \mathrm{L})$, Sulphate (100mg/L), Conductivity (1000us/cm), Lead 
$(0.01 \mathrm{mg} / \mathrm{L})$, Cyanide $(0.01 \mathrm{mg} / \mathrm{L})$, Cadmium $(0.003 \mathrm{mg} / \mathrm{L})$ Arsenic $\quad(0.01 \mathrm{mg} / \mathrm{L}), \quad$ Barium $\quad(0.7 \mathrm{mg} / \mathrm{L}), \quad$ Mercury $(0.01 \mathrm{mg} / \mathrm{L})$, Free Residual Chloride $(0.2-0.25 \mathrm{mg} / \mathrm{L})$, Poly Aromatic HC $(0.007 \mathrm{mg} / \mathrm{L})$, Total Organic Carbon $(5.0 \mathrm{mg} / \mathrm{L})$, Mineral oil $(0.003 \mathrm{mg} / \mathrm{L})$, Phenol $(0.001 \mathrm{mg} / \mathrm{L}), 2$, 4, 6TrichloroPhenol $(0.02 \mathrm{mg} / \mathrm{L})$, are within the required WHO standard recommended for domestic use while Fluoride $(1.02 \mathrm{mg} / \mathrm{L})$ is above the WHO standard Fluoride $(1.0 \mathrm{mg} / \mathrm{L})$.

The analysis shows that Color (15TCU), Taste/Odor (Unobjectionable), Temperature (Ambient), Turbidity (5.0NTU), Chloride (100mg/L), Fluoride (1.0mg/L), Copper $(1.0 \mathrm{mg} / \mathrm{L})$, Iron $(0.3 \mathrm{mg} / \mathrm{L})$, Nitrate $(50 \mathrm{mg} / \mathrm{L})$, Nitrite $(0.2 \mathrm{mg} / \mathrm{L})$, Magnesium $(0.2 \mathrm{mg} / \mathrm{L})$, Zinc $(3.0 \mathrm{mg} / \mathrm{L})$, TDS $(500 \mathrm{mg} / \mathrm{L}), \quad \mathrm{Ph}(6.5-8.5)$, Hardness $(150 \mathrm{mg} / \mathrm{L})$, Total Alkalinity $(50 \mathrm{mg} / \mathrm{L}), \mathrm{H}_{2} \mathrm{~S}(0.05 \mathrm{mg} / \mathrm{L})$, Sulphate $(100 \mathrm{mg} / \mathrm{L})$, Conductivity (1000us/cm), Lead $(0.01 \mathrm{mg} / \mathrm{L})$, Cyanide $(0.01 \mathrm{mg} / \mathrm{L}), \quad$ Arsenic $(0.01 \mathrm{mg} / \mathrm{L})$, Barium $(0.7 \mathrm{mg} / \mathrm{L})$, Mercury $(0.01 \mathrm{mg} / \mathrm{L})$, Free Residual Chloride $(0.2-0.25 \mathrm{mg} / \mathrm{L})$, Poly Aromatic HC $(0.007 \mathrm{mg} / \mathrm{L})$, Total Organic Carbon $(5.0 \mathrm{mg} / \mathrm{L})$, Mineral oil $(0.003 \mathrm{mg} / \mathrm{L})$, Phenol $(0.001 \mathrm{mg} / \mathrm{L}), 2$, 4 , 6-TrichloroPhenol $(0.02 \mathrm{mg} / \mathrm{L})$, are within the required WHO standard recommended for domestic use while Manganese $(0.6 \mathrm{mg} / \mathrm{L})$ and Cadmium $(0.012 \mathrm{mg} / \mathrm{L})$ are above the WHO standard of Manganese $(0.2 \mathrm{mg} / \mathrm{L})$, and Cadmium $(0.003 \mathrm{mg} / \mathrm{L})$.

\subsection{The Suitability of the Surface Water of Usuma River for Human Consumption}

The study shows that most of the associate parameters analyzed in point 1 are within the safe limits by WHO standards except for Nitrite $(7.00 \mathrm{mg} / \mathrm{l})$ and Magnesium $(0.27 \mathrm{mg} / \mathrm{l})$ which are above the recommended limits considered safe by WHO Nitrite $(0.2 \mathrm{mg} / \mathrm{l})$ and Magnesium $(0.20 \mathrm{mg} / \mathrm{l})$. It therefore means that the surface water collected from the study area has a higher concentration of Nitrite and Magnesium and are likely to pose danger on humans if used for drinking purpose.

The study shows that most of the associate parameters analysed in point 2 are within the safe limits by WHO standards except for Fluoride $(1.02 \mathrm{mg} / \mathrm{l})$ which is above the recommended limit considered safe by WHO Fluoride of $1.0 \mathrm{mg} / \mathrm{L}$. It therefore means that the surface water collected from the study area has a higher concentration of Fluoride and it is unsafe and likely to pose danger on humans if used for drinking purpose.

The study shows that most of the associate parameters analysed in point 3 are within the safe limits by WHO standards except for Manganese $(0.60 \mathrm{mg} / \mathrm{l})$ which is above the recommended limits considered safe by WHO Manganese $(0.2 \mathrm{mg} / \mathrm{l})$. It therefore means that the surface water collected from the study area has a higher concentration of manganese and it is unsafe and likely to pose danger on humans if used for drinking purpose.

\subsection{Consultation with Health and Water Quality Expert}

The consultation revealed that the quality of water entering the body must be considerably high so as to exclude the ingestion of pathogenic organisms and toxic chemicals. According to their book, [31], heavy metals such as mercury, lead, aluminium, strontium, arsenic, asbestos, hydrocyanic acid must not be present in water, foods, and water products. Even when any chemical is present as a nutrient in water, it must be within an acceptable and safe limit. Excessive salt consumption can lead to cardiovascular diseases including hypertension. Consequently, patients suffering from waterborne diseases occupy more than half of the world's hospital beds.

The Health and Water Quality Expert also stated that pollution of water happens on many levels and affects human health in many ways. There are numerous waterborne diseases that are a direct result of water pollution; Ingestion of poorly treated water can cause diarrhoea, cholera, stomach infections and typhoid. Dirty or polluted water is the preferred breeding ground for mosquitoes and other pests. Mosquito bites adversely affect human health and can cause diseases such as Malaria, Filariasis, Dengue and Chikungunya. Water pollution also affects the health of water animals such as fish. When humans consume these sick fish, the infections get passed and can take more serious form in the human body. Apart from fish, water pollution also affects other plants and animals which in turn affects human health. If we consume food that has already been infected, we are bound to fall ill. People can get diseases such as hepatitis by eating seafood that has been poisoned. In many poor nations, there is always outbreak of cholera and diseases as a result of poor drinking water treatment from contaminated waters.

High salts content of raw water results in nauseous, saline taste with purgative tendency and dehydration. Salts containing nitrates or nitrites are known to cause Methemoglobinemia (symptoms include shortness of breath and blue-tinted skin) often called blue baby syndrome in children, and fluorides may result in dental fluorosis. The organic nitrates may undergo further reactions to form nitrosamines, which are highly carcinogenic.

\section{Conclusion}

The results of water analysis carried out in the study area indicates that the level of contamination of Usuma river in Phase IV, significantly affect its quality, having compared the result with WHO levels. The traces of nitrite, fluoride, magnesium, managanese and cadmium observed with slight change in turbidity and alkalinity in some samples can be said to be significant enough to warrant panic as well as pose danger to human health if consumed. There are other diseases traceable to the consumption of such water. Eg; Typhoid Fever, Methemoglobinemia, Phileriasis, Diahorea, Chicken Pox, Staphylococcus and to mention but few. Cadmium poisoning has been associated with kidney disease, hypertension, and possibly genetic mutation. The presence of these physio-chemical components in higher concentration has made the water in Usuma River, Phase IV 
un-fit for domestic use, especially as drinking water and this may pose threat to the health of the people in the study area.

The study also revealed that waste dumped at the river bank is primarily responsible for the contamination considering the heap of waste found at the bank of the river forming slopes for easy runoff into the river.

\section{Acknowledgements}

The authors would like to thank the Staff of the Department of Pollution Control and Environmental Health and Staff at the Department of Environmental Management, Nasarawa State University, Keffi for their immense support and insight during this study.

\section{References}

[1] Omoleke I. I. (2004). Management of Environmental Pollution in Ibadan, an African city: The Challenges of health hazard facing government and the people. J. Hum. Ecol. 15 (4): 265-275 Operating Procedure numbers 2013. [Retrieved from: Operations. Lewis Publishers, CRC Press Company. Florida, USA, pp 547, 551.

[2] UNESCO (2003). Water for People, Water for Life: UN World Water Development Report (WWDR), Paris, United Nations Educational, Scientific and Cultural Organization.

[3] Fakayode, S. O. (2005) Impact assessment of industrial effluent on water quality of the Receiving Alaro river in Ibadan Nigeria AJEAM-RAGEE 10: 1-13.

[4] Ajayi S. O. and Osibanji O. (1981). Pollution studies on Nigeria Rivers 11; Water quality of some Nigerian Rivers. Environ. Pollution. Series 2: 87-95.

[5] UN Report 2012 The United Nations World Water Development; Managing Water under Uncertainty and Risk: Executive summary.

[6] Oyediran, A. B. O., (1994), A key note Address at the 6th Annual workshop of Nigerian Environmental study/Action Team on 24th October, 1994, at the university of Ibadan conference centre, Ibadan.

[7] Gentry, B. and Fernandez I. (1997), "Evolving publicprivate partnerships: General Themes and urban water examples," OECD workshop on Globalisation and the Environment: New challenges for the public and private sectors. 13-14 November.

[8] DETR (U. K. Department of the Environment, Transport and the Regions), (1999), "A Better Quality of Life". Chapter 8managing the Environment and Resources. 17 may. London.

[9] EIONET, (1999), Second Annual EIONET Workshop on Waste. European Topic centre on waste. September. Vienna.

[10] Diaz, L. F. and Golueke, C. G., (1985), 'Solid waste management in Developing countries", Biocycle, Vol. 26, NO. 1 pg. 46-51.

[11] Barnard, R and Olivetti, G (1990), ' 'limiting Environmental impact by waste management; Resource conservation and Recycling Vol. 4, No. 1 and 2,pg. 21-34.
[12] Hassan, P (1991), "urban solid waste management in Banding: Towards an Integrated Resource Recovery system" Environment and urbanization. Vol. 3, No. 1.

[13] Benjamin, C. G., (1989), “improving solid waste management in the contest of metropolitan Development in metro manila," Regional Development Dialogue, Vol. 10, No. 3, pg. 40-46.

[14] Auschwitz, J. (1996), Community-Based solid waste management and waste supply projects; problem $\mathrm{s}$ and solutions compared http://www.waste.nl/docpd/WDO2.pdf.

[15] Hoornweg, D. and Thomas, L., (1999), what a waste; solid waste management in Asia. Washignton, D. c: The World Bank, urban Development division urban and local Government working paper series. Vol. 1, No. 19pg. 5-13.

[16] Peters, N. E and Meybeck, M. (2000) Water Quality Degradation Effects on Freshwater Availability: Impacts of Human Activities, Water International, 25: 2, 185-193.

[17] Chapman, D. (1996), Water Quality Assessments. A Guide to Use of Biota, Sediments and Water in Environmental Monitoring, ( $2^{\text {nd }}$ ed.), London, F \& FN Spon.

[18] Lee, C. C. (2007). Handbook of Environmental Engineering Calculations. $2^{\text {nd }}$ Edition. McGraw-Hill Professional Publishing, New York. pp 1.464.

[19] Liu, D (1999). Environmental Engineers Handbook. CRC Press LLC. Florida, USA. pp 539, 546, 1067.

[20] Metcalf and Eddy (2003). Wastewater Engineering Treatment and Reuse. $4^{\text {th }}$ Edition. McGraw - Hill, New York. pp 1, 10, 58,69 .

[21] Spellman R. F. (2003). Handbook of Water and Wastewater Treatment Plant.

[22] Pescod, M. B. (1992). Wastewater Treatment and Use in Agriculture. FAO irrigation and drainage paper 47. Food and agriculture Organization of the United Nations. Rome, Italy.

[23] Awuah, E. (2006). Pathogen Removal Mechanisms in Macrophyte and Algal Waste Stabilization Ponds. Doctoral Dissertation, UNESCO-IHE Institute for Water Education. Taylor and Francis Group/Balkema, Rotterdam, the Netherlands. 2-10.

[24] Weiner, R. F., Matthews, R., Peirce, J. J. and Vesilind, P. A. (2003). Environmental Engineering. 4th Edition. Butterworth Heinemann Publications. New York, USA. pp 153.

[25] Helmer, R. (1997). Water Quality Monitoring: National and International Approaches. Hydrological, Chemical and Biological Processes of Transformation and Transport of Contaminants in Aquatic Environments. Proceedings of the Rostov-on-Don Symposium, May 1993. IAHS (219).

[26] Strauss, M. (2000). Health (Pathogen) Considerations Regarding the Use of Human Waste in Aquaculture. Swiss Federal Institute for Environmental Science and Technology (EAWAG). Department of Water and Sanitation in Developing Countries (SANDEC). Duebendorf, Switzerland.

[27] Abdul-Razak, A., Asiedu A. B., Entsua-Mensah, R. E. M. and de Graft-Johnson, K. A. A. (2009). Assessment of the Water Quality of the Oti River in Ghana. West African Journal of Applied Ecology, Vol. 15. pp 1-2. 
[28] USEPA (2007). Surface Water Sampling. Science and Ecosystem Support Division (SESD) Operating Procedure. US-EPA, Region 4, Athens, Georgia Number: SESDPROC201-R1. [Retrieved from: www.epa.gov/region4/sesd/fbqstp/Surfacewater-Sampling.pdf Date accessed: 26th January, 2011].

[29] United States Environmental Protection Agency USEPA (Last Updated on March 10, 2017.
[30] Tennessee Valley Authority (2009). Standard Operating Procedure for Surface. The Netherlands. 301-309.

[31] The Sanitarian and His Work (2016). Second Edition; Joseph O. O, Zakariyau A, Ebisike A. O (Former Registrar, EHORECON Abuja, Nig.), Nathaniel A. O, Emmanuel E, Stephen A. B, David O, Samuel N. K, Bamidele O, Andy U and Ayodele Mesuleya. 